\title{
Frequency of and risk factors associated to Leptospira spp. seropositivity in goats in the state of Sergipe, Northeastern Brazil
}

\section{Huber Rizzo ${ }^{*}$ Tatiane Rodrigues da Silva ${ }^{2}$ Jeferson Silva Carvalhoo $^{3}$ Felipe Apolônio Marinho ${ }^{4}$ Hilderley de Almeida Santos ${ }^{4}$ Wellington Santos Silva Júnior ${ }^{4}$ Mario Augusto Reyes Alemán ${ }^{5}$ José Wilton Pinheiro Júnior ${ }^{1}$ Vanessa Castro $^{6}$}

${ }^{1}$ Departamento de Medicina Veterinária, Universidade Federal Rural de Pernambuco (UFRPE), 52171-900, Recife, PE, Brasil. E-mail: hubervet@gmail.com. "Corresponding author.

${ }^{2}$ Centro de Saúde e Tecnologia Rural, Universidade Federal da Campina Grande (UFCG), Patos, PB, Brasil.

${ }^{3}$ Programa de Pós-graduação em Ciência Veterinária, Universidade Federal Rural de Pernambuco (UFRPE), Recife, PE, Brasil.

${ }^{4}$ Médico Veterinário Autônomo, Aracaju, SE, Brasil.

${ }^{5}$ Programa de Pós-graduação em Clínica Veterinária, Faculdade de Medicina Veterinária e Zootecnia da Universidade de São Paulo (FMVZ/USP), São Paulo, SP, Brasil.

${ }^{6}$ Laboratório de Doenças Bacterianas da Reprodução, Instituto Biológico de São Paulo, São Paulo, SP, Brasil.

ABSTRACT: The objective of this study was to determine the frequency and factors associated with the occurrence of seropositivity for Leptospira spp. in goat herds in the state of Sergipe, Brazil, on the basis of the analysis of 675 samples collected from 41 properties in $2013-2014$. Analysis of anti-Leptospira spp. antibodies revealed that 25.74\% goats (194) were seropositive and that 90.24\% (37) of the properties had at least one infected goat. The most prevalent serogroup was Icterohaemorrhagiae ( $85.57 \%)$; although, the study animals were reactive to other serogroups: Australis (5.15\%), Pomona (3.61\%), Sejroe (3.09\%), and Pyrogenes (2.58\%) had titers $\leq 400$ in $96.91 \%$ of cases. The origin of the water source [still water source $(O R=3.86)]$ was associated with seropositivity. Results reflected the importance of adopting appropriate management practices for herds in Sergipe.

Key words: water source, leptospirosis, serogroup, Icterohaemorrhagiae, test microscopic agglutination test.

Frequência e fatores de riscos associados a caprinos soropositivos a Leptospiras spp. no Estado de Sergipe, Nordeste do Brasil

RESUMO: O objetivo deste estudo foi determinar a frequência e os fatores associados à soropositividade para Leptospira spp. em caprinos do Estado de Sergipe, Nordeste do Brasil, utilizando 675 animais de 41 propriedades no periodo de 2013 e 2014 . A frequência de positividade entre os animais foi de 25,74\% (194), e em 90,24\% (37) das propriedades houve pelo menos um animal soropositivo. $O$ sorogrupo reagente predominante foi o Icterohaemorrhagiae (85,57\%), com presença também de animais reagentes para Australis (5,15\%), Pomona (3,61\%), Sejroe (3,09\%) e Pyrogenes (2,58\%) com títulos $\leq 400$ em 96,91\% dos casos. A origem da água fornecida (água parada) $(O R=3,86)$ foi o fator associado à presença de caprinos positivos. Ressalta-se a importância da adoção de práticas de manejo adequadas nos rebanhos caprinos sergipanos.

Palavras-chave: fonte de água, leptospirose, sorogrupo, Icterohaemorrhagiae, teste de soroaglutinação microscópica.

\section{INTRODUCTION}

Leptospirosis is a major public health problem in Brazil with an annual average rate of 3,780 human cases between 2000 and 2015, 9.6\% (364) of which were lethal. In the country's Northeastern region and in the state of Sergipe, lethality is as high as $12.8 \%(87 / 681)$ and $24.1 \%(10.6 / 44)$, respectively (SINAN/SVS/MS, 2017a, b). Leptospirosis is caused by spirochetes of the genus Leptospira. Twenty-five serogroups and approximately 300 serovars belonging to 25 serogroups can infect domestic animals, wildlife, and humans. On rural properties, transmission occurs primarily via the urine of infected animals (GOMES,
2013; HIGINO \& AZEVEDO, 2014). Accordingly, rural workers in Jamaica who have contact with goats have a 3.52 times higher chance of presenting symptoms of the disease (KEENAN et al., 2010).

Goats usually present chronic infection, with a predominance of embryonic absorption, miscarriage, neonatal mortality, and hemorrhagic jaundice. In the acute form of the disease, a sudden onset of fever, anemia, jaundice, and hemoglobinuria occur, leading to death (MARTINS et al., 2012; HIGINO \& AZEVEDO, 2014).

In the Northeastern region of Brazil, surveys were performed in the states of Rio Grande do Norte, Ceará, Paraíba, and Pernambuco. The rate of seropositive goats based on the microscopic 
agglutination test (MAT) ranged from $1.5 \%$ to $33.3 \%$. The most common serogroups in the Brazilian states were Icterohaemorrhagiae, which were positive in a sample from Ceará (FAVERO et al., 2002); Australis, Djasiman, Celledoni, Semaranga, and Sejroe, which were reported in the state of Paraíba (FAVERO et al., 2002; HIGINO et al., 2013; COSTA et al., 2016); Autumnalis, which were detected in Rio Grande do Norte; (ARAÚJO NETO et al., 2010); and Canicola and Autumnalis, which were reported in Pernambuco (CUNHA et al., 1999). Surveys were conducted in other Brazilian states, including Rio Grande do Sul, Santa Catarina, Rio de Janeiro, Espírito Santo, and Minas Gerais, and the infection rates were 2.4\%$35.47 \%$ (FAVERO et al., 2002; SCHMIDT et al., 2002; LILENBAUM et al., 2007b; LILENBAUM et al., 2008; DOS SANTOS, et al., 2012; CORTIZO et al., 2015; TOPAZIO et al., 2015).

The only serogroup isolated from goats in Brazil is Grippotyphosa, which has been reported in cultivated urine samples (LILENBAUM et al., 2007a). Studies involving goat herds from Brazilian states reported the following risk factors associated with the occurrence of Leptospira spp.: rodent infestations and a history of infertility in goats in the state of Paraíba (HIGINO et al., 2013); contact with sheep and the presence of concentrate in animal feed in the state of Santa Catarina (TOPAZIO et al., 2015); an intensive breeding system, presence of purebreds, animals aged $>12$ months, breeding systems involving other animal species, and farms that employed outside manual labor in the state of Minas Gerais (SANTOS et al., 2012); a semi-intensive farming system, a still water source (a well), and cases of miscarriage in the state of Espírito Santo (CORTIZO et al., 2015); and the tropical climate, absence and/or low frequency of veterinary care, and access to pastures in the state of Rio de Janeiro (LILENBAUM et al., 2008).

Knowledge regarding leptospirosis in goats is still scarce, and monitoring measures are still empirical because of the lack of information on infection, particularly in tropical conditions (MARTINS \& LILENBAUM, 2014). Therefore, the aim of this study was to determine the frequency of Leptospira spp. seropositivity in goat herds in the state of Sergipe, Brazil, and to identify risk factors.

\section{MATERIALS AND METHODS}

The study was conducted in the Brazilian state of Sergipe $\left(9^{\circ} 30^{\prime} 49^{\prime \prime}\right.$ and $11^{\circ} 34^{\prime} 05^{\prime \prime}$ latitude and $3623^{\prime} 40^{\prime \prime}$ and $38^{\circ} 15^{\prime} 00^{\prime \prime}$ longitude), which has a land area of $21,918,454 \mathrm{~km}^{2}$ and is divided into three semiarbitrary mesoregions (the East region, the Agreste agricultural region, and the semiarid Sertão outback). The Northeastern region of Brazil has 8,109,672 goat heads, and Sergipe is the state with the smallest goat population in this region, with 23,647 animals. Of these, 8,265 are located in the Sertão mesoregion, 11,840 are located in the Agreste region, and 3,542 are located in the East region (IBGE, 2014). Sample size was calculated using the method described by Thrusfield (2007) according to the following parameters: a population of $23,647,000$ goats (IBGE, 2014), a confidence interval of $95 \%$, an error of $5 \%$, and a prevalence of $11.83 \%$, which represents the mean of serological surveys in goats in the Northeastern region of Brazil (CUNHA et al., 1999; FAVERO et al., 2002; ARAÚJO NETO et al., 2010; HIGINO et al., 2013; COSTA et al., 2016). This process resulted in a minimum sample of 369 goats (123 goats per mesoregion). Samples were collected in 2013 and 2014, and 675 blood samples were obtained from goats from 41 properties. Seven to 20 animals, of different breeds which were, apparently healthy and which were older than 6 months of age, were selected randomly from each herd. Properties were located in 15 municipalities of the three mesoregions: East, Agreste or Sertão. A total of 178, 233, and 264 samples were collected from each of these mesoregions, respectively. The choice of cities and properties was based on state divisions, convenience, ease of access, and the availability of goat ranches.

A structured questionnaire including closed-ended questions was designed to obtain information on the handling characteristics and the herd facilities to assess the factors associated with Leptospira spp. infection. Blood samples were collected from the animals' jugular veins using sterile vacuum tubes, centrifuged at $1,600 \mathrm{~g}$ for $10 \mathrm{~min}$, transferred to $2-\mathrm{mL}$ polypropylene tubes, and frozen at $-20^{\circ} \mathrm{C}$ until processing. Microscopic agglutination tests were conducted in the Laboratory for Reproductive Bacterial Diseases in the Biological Institute of São Paulo to detect antibodies against Leptospira spp. using a collection of 22 serovars belonging to 18 serogrups (Leptospira interrogans serovars Australis, Bataviae, Bratislava, Butembo, Canicola, Celledoni, Copenhageni, Djasiman, Grippotyphosa, Hebdomadis, Icterohaemorrhagiae, Pomona, Pyrogenes, Wolff; Leptospira borgpeterseni serovars Autumnalis, Castellonis, Hardjobovis Javanica, and Tarassovi; Leptospira santarosai serovars Shermani; Leptospira kirschneri serovars Cynopteri; and Leptospira noguchii serovars 
Panama) and leptospires were grown in a modified EMJH medium (ALVES et al., 1996).

Samples with visible agglutination at a dilution of 1:100 were considered positive (FAINE et al., 1999). Absolute and relative frequencies were determined using descriptive statistical analysis. The risk factors were evaluated by analyzing the univariate variables of interest using Pearson chisquared test or Fisher exact test when necessary. Logistical regression analysis was performed, in which the dependent variable for Leptospira spp. infection was the MAT results (positive or negative). The independent or explanatory variables considered in the model were those that exhibited a statistical significance $<0.20$. This probability was established so that possible risk factors for infection were not excluded from the analysis (HOSMER \& LEMESHOW, 1989). The logistic regression model was considered as risk factor variables with $\mathrm{P}<0.05$. The Epi Info software version 3.5.1 was used to make the statistical calculations.

\section{RESULTS}

Of the 675 goat sera assayed with the MAT, 28.74\% (194) were positive, and 90.24\% (37/41) of the properties had at least one positive animal (Table 1). Moreover, 194 serum agglutination reactions were positive, with titers of 100 in $60.31 \%$ (117/194), 200 in $29.38 \%$ (57/194), 400 in $7.22 \%$ (14/194), 800 in $2.06 \%$ (4/194), and 1,600 in $0.82 \%$ $(2 / 194)$ cases.

Reactions against eight serogroups were observed, the most common of which was Icterohaemorrhagiae, in $85.57 \%$ (166) cases, followed by Australis $(5.15 \%, \mathrm{n}=10)$, Pomona $(3.61 \%, n=7)$, Sejroe $(3.09 \%, n=6)$, and Pyrogenes $(2.58 \%, \mathrm{n}=5)$. The only significant variables in the univariate analysis (Table 2 ) and that were confirmed in the multivariate logistic regression $(\mathrm{P}<0.001)$ were the animals' water source. The presence of goats seropositive for Leptospira spp. was associated with the ingestion of still water, including supplies from buckets, wells, dams, ponds $(\mathrm{P}<0.001, \mathrm{OR}=3.86$ and 95\% CI=2.11-7.05).

\section{DISCUSSION}

Our results indicated a high frequency of goats exposed to Leptospira in the state of Sergipe, and this rate was one of the largest ever reported in a Brazilian study. These high values corroborated those of prior studies conducted in Pernambuco
(CUNHA et al., 1999), in the municipality of Uberlândia, Minas Gerais (SANTOS et al., 2012), and in the western and mountainous mesoregions of Santa Catarina (TOPAZIO et al., 2015), with rates between $31.3 \%$ and $35.47 \%$. However, none of these studies collected samples from all the mesoregions present in their respective states, and in three cases, the number of samples assayed with MAT was much lower than that in the current study. Other surveys in the Northeastern region of Brazil reported lower rates of infection, ranging from $1.5 \%$ to $15.67 \%$ in the states of Rio Grande do Norte (ARAÚJO NETO et al., 2010), Paraiba, and Ceará (FAVERO et al., 2002; HIGINO et al., 2013; COSTA et al., 2016.).

The titers obtained were low, and this result agrees with those of other Brazilian studies (SCHMIDT et al., 2002; LILENBAUM et al., 2007b; ARAÚJO NETO et al., 2010; HIGINO \& AZEVEDO, 2014; COSTA et al., 2016). This result also indicated chronic infection, which may go unnoticed, as well as low exposure to the agent, suggesting that serological studies are an essential part of control measures in goat herds. The chronic nature of infection indicated that goats eliminate the bacteria into the environment, which increases the risk of transmission of this agent to other animals.

MARTINS et al. (2012) reported high antibody titers $(\geq 800)$ in a goat herd in the state of Rio de Janeiro, and the disease involved cases of miscarriage, embryo absorption, and neonatal death; although, the goats seemed healthy and only $3.28 \%$ $(8 / 244)$ of the reactions had titers $\geq 800$.

Among the serogroups, Icterohaemorrhagiae was the most frequent $(85.57 \%)$ in Rio Grande do Sul (SCHMIDT et al., 2002) and Santa Catarina (TOPAZIO et al., 2015), where farmers reported rodent infestations. The same situation may be occurring among herds in Sergipe because the positivity to this serogroup is associated with the presence of Rattus norvegicus and other rodent species from which this serogroup was isolated, including the black rat (Rattus ratus) and the Brazilian guinea pig (Cavia aperea azarae) (VIRGINIE et al., 2002; OLIVEIRA et al., 2013), indicating that the high transmission of Leptospira spp. in herds in Sergipe may be associated with the presence of rodents.

The presence of rodent infestations because of failures in health management, as proven by the substantial presence of serogroups associated with these reservoirs and with the consequent contamination of water sources, may explain the high rate of seropositive goat herds in Sergipe 
Table 1 - Percentage of goats that tested seropositive to Leptospira spp. using a microscopic agglutination test (MAT), organized by municipality and mesoregion in the state of Sergipe, Brazil, 2013-2014.

\begin{tabular}{|c|c|c|}
\hline Municipality & $\begin{array}{l}\% \text { (Number of properties with positive } \\
\text { goats/total number of properties) }\end{array}$ & $\begin{array}{c}\% \text { (Number of seropositive goats/total } \\
\text { number of goats) }\end{array}$ \\
\hline Aracaju & $100(3 / 3)$ & $21.53(11 / 52)$ \\
\hline Estância & $100(1 / 1)$ & $55(11 / 20)$ \\
\hline Itaporanga D'ajuda & $100(1 / 1)$ & $20(4 / 20)$ \\
\hline Nossa Senhora do Socorro & $100(1 / 1)$ & $44.44(8 / 18)$ \\
\hline Salgado & $100(2 / 2)$ & $32.14(9 / 28)$ \\
\hline São Cristóvão & $100(1 / 1)$ & $45(9 / 20)$ \\
\hline Neópolis & $100(1 / 1)$ & $5(1 / 20)$ \\
\hline Total East mesoregion & $100(10 / 10)$ & $29.76(53 / 178)$ \\
\hline Itabaiana & $100(1 / 1)$ & $60(12 / 20)$ \\
\hline Lagarto & $100(1 / 1)$ & $35(7 / 20)$ \\
\hline Macambira & $66.67(2 / 3)$ & $14.29(6 / 42)$ \\
\hline Poço Verde & $81.82(9 / 11)$ & $24.5(37 / 151)$ \\
\hline Total Agreste mesoregion & $87.5(14 / 16)$ & $26.61(62 / 233)$ \\
\hline Canindé de São Francisco & $100(6 / 6)$ & $38.33(46 / 120)$ \\
\hline Nossa Senhora da Glória & $83.33(5 / 6)$ & $22.83(21 / 92)$ \\
\hline Pedra Mole & $100(1 / 1)$ & $7.69(1 / 13)$ \\
\hline Pinhão & $100(2 / 2)$ & $28.21(11 / 39)$ \\
\hline Total Sertão mesoregion & $93.33(14 / 15)$ & $29.92(79 / 264)$ \\
\hline Total & $90.24(37 / 41)$ & $28.74(194 / 675)$ \\
\hline
\end{tabular}

(90.24\%), as also observed in Rio de Janeiro, Santa Catarina and municipality of Uberlândia, with rates of $100 \%$ (48/48), 90\% (108/120) and 100\% (11/11), respectively (LILENBAUM et al., 2007b; SANTOS et al., 2012; CORTIZO et al., 2015).

In Paraíba, HIGINO et al. (2013) reported that the presence of rodents in rural properties was a risk factor for infection of goats with Leptospira spp. $(\mathrm{OR}=2.78,95 \% \mathrm{CI}=1.22-6.31$, and $\mathrm{P}=0.015)$. However, no positive reaction was observed for the Icterohaemorrhagiae serogroup. The most frequent serogroup was Australis, as reported by ARAÚJO NETO et al. (2010) in Rio Grande do Norte. This serogroup was the second most frequent in goats from Sergipe, and this finding confirmed the importance of rodents in the spread of the disease because the hosts include not only pigs and dogs but also the South American water rat (Nectomys squamipes) (GOMES, 2013; OLIVEIRA et al., 2013), a semiaquatic rat that typically inhabits the banks of streams, rivers, and flooded areas in the Northeastern region of Brazil, particularly on the basin of the São Francisco River from Bahia to Pernambuco (GENTILE, 2010).

The presence of these reservoirs, which were reported by $63.41 \%(26 / 41)$ of the goat owners in Sergipe, is usually associated with poor sanitation practices such as the accumulation of waste, lack of hygiene during food and water handling, poor food storage practices, poor water quality, and presence of wild and synanthropic animals around the properties, favoring the increased contact of these animals with livestock and humans (SILVA et al., 2014). As a result, the facilities are constantly exposed to the etiological agent via the urine of infected animals, particularly in still water because it favors the survival of bacteria in the environment (GOMES, 2013).

These infection sources and the availability of still water (wells, dams, buckets) were associated $(\mathrm{OR}=3.86)$ with the presence of animals reactive to Leptospira spp. in the study herds. These findings are consistent with those of CORTIZO et al. (2015) in Espírito Santo (OR=1.8), who also reported high positive rates $(97 \%)$ for the Icterohaemorrhagiae serogroup. Reproductive problems presented by goats infected with this serogroup on a property in the state of Rio de Janeiro led to the adoption of corrective measures for rodent control, including trapping, use of rodenticides, decreased access to stored feed, and restriction of goats access to flooded areas. After 1 year, there was a significant reduction in the rate of reproductive failure (MARTINS et al., 2012). 
Table 2 - Percentage of Leptospira spp. seropositive goats from rural properties in the Brazilian state of Sergipe in 2013-2014 organized by variable and number of goats.

\begin{tabular}{|c|c|c|c|}
\hline Variable & $\mathrm{N}$ & SAM $(\%)$ & Value $\mathrm{p}$ \\
\hline \multicolumn{4}{|c|}{ 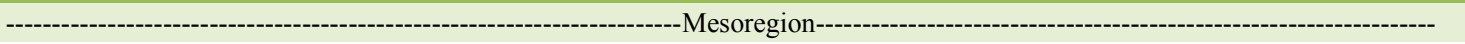 } \\
\hline East & 178 & $53(29.77)$ & \multirow{3}{*}{0.673} \\
\hline Agreste & 233 & $62(26.61)$ & \\
\hline Sertão & 264 & $79(29.92)$ & \\
\hline \multicolumn{4}{|c|}{ 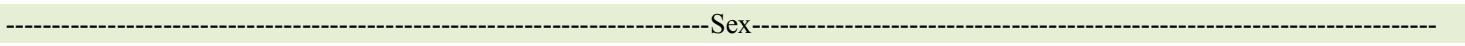 } \\
\hline Female & 566 & $176(31.01)$ & \multirow{2}{*}{$<0.001$} \\
\hline Male & 109 & $18(16.51)$ & \\
\hline \multicolumn{4}{|c|}{ 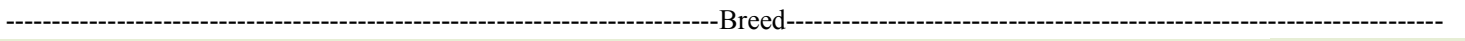 } \\
\hline Anglo Nubiana & 60 & $10(16.67)$ & \multirow{6}{*}{0.017} \\
\hline Boer & 55 & $17(30.91)$ & \\
\hline Parda Alpina & 16 & $3(18.74)$ & \\
\hline Saanen & 215 & $65(30.23)$ & \\
\hline Undefined & 321 & $94(29.28)$ & \\
\hline Toggenburg & 8 & $6(75)$ & \\
\hline \multicolumn{4}{|c|}{ - } \\
\hline Meat & 298 & $86(28.86)$ & \multirow{2}{*}{0.509} \\
\hline Milk & 377 & $108(28.65)$ & \\
\hline \multicolumn{4}{|c|}{ 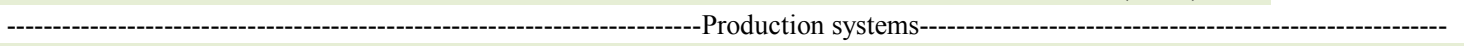 } \\
\hline Extensive & 114 & $41(35.96)$ & \multirow{3}{*}{0.016} \\
\hline Intensive & 108 & $39(36.11)$ & \\
\hline Semi-extensive & 453 & $115(25.39)$ & \\
\hline \multicolumn{4}{|c|}{ 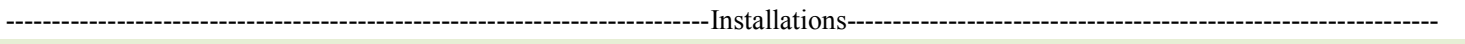 } \\
\hline Brick floor pen & 162 & $41(25.31)$ & \multirow{4}{*}{0.509} \\
\hline Dirt floor pen & 106 & $32(30.19)$ & \\
\hline Slatted floor pen & 225 & $63(28)$ & \\
\hline None & 182 & $59(32.42)$ & \\
\hline \multicolumn{4}{|c|}{ - } \\
\hline Covered trough & 370 & $96(25.95)$ & \multirow{4}{*}{0.123} \\
\hline Uncovered trough & 188 & $56(29.79)$ & \\
\hline Not available & 97 & $34(35.05)$ & \\
\hline On the ground & 20 & $9(45)$ & \\
\hline \multicolumn{3}{|l|}{---------------------' } & --------- \\
\hline Flowing streams & 117 & $13(11.11)$ & \multirow{2}{*}{$<0.001$} \\
\hline Still water & 559 & $377(67.44)$ & \\
\hline \multicolumn{4}{|c|}{ - } \\
\hline Open place & 138 & $55(39.85)$ & 0.007 \\
\hline Place closed & 517 & $135(26.11)$ & \\
\hline Place open and closed & 20 & $5(25)$ & \\
\hline \multicolumn{4}{|c|}{ - } \\
\hline Yes & 421 & $128(30.4)$ & \multirow{2}{*}{0.155} \\
\hline No & 254 & $67(26.38)$ & \\
\hline \multicolumn{3}{|l|}{----------- } & --------- \\
\hline Yes & 440 & $136(30.91)$ & \multirow{2}{*}{0.062} \\
\hline No & 235 & $59(25.11)$ & \\
\hline \multicolumn{4}{|c|}{ 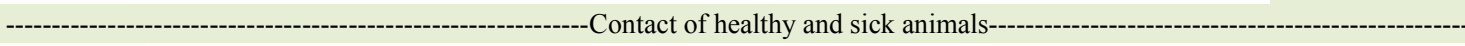 } \\
\hline Yes & 413 & $122(29.53)$ & 0359 \\
\hline No & 262 & $73(27.86)$ & 0.559 \\
\hline 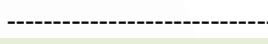 & ations & ---------------- & -------- \\
\hline Yes & 515 & $155(30.09)$ & \\
\hline No & 160 & $40(25)$ & 0.128 \\
\hline
\end{tabular}




\section{CONCLUSION}

The occurrence of seropositivity for Leptospira spp. in goat herds in the Brazilian state of Sergipe demonstrates the wide distribution of this etiological agent in the state. Our results indicated that the primary method of maintenance and dissemination of spirochetes were sources of still water contaminated with rodent urine. Therefore, sanitary control measures should be adopted, particularly methods that include pest management practices, considering the predominance of the Icterohaemorrhagiae serogroup.

\section{ACKNOWLEDGMENTS}

The authors are grateful to the Scientific Research and Extension Group in Buiatrics at Universidade Pio Décimo de Aracaju, Sergipe, for sample collection.

\section{BIOETHICS AND BIOSSECURITY COMMITTEE APPROVAL}

This study was approved by the Bioethics Committee of Universidade Pio Décimo under Protocol number 06/2011 from April 16, 2011.

\section{REFERENCES}

ALVES, C.J. et al. Influence of environmental factors on the proportion of goat serum-reactors for leptospirosis in five breeding centers in the State of Paraíba, Brazil. Arquivos do Instituto Biológico, São Paulo, v.63. n.2, p.11-18, 1996.

ARAÚJO NETO, J.O. et al. Seroprevalence of leptospirosis in goats of the Seridó Oriental microregion, Rio Grande do Norte State, Northeastern Brazil, and risk factors research. Brazilian Journal of Veterinary Research and Animal Science, São Paulo, v.47, p.150155, 2010. Available from: <http:/www.revistas.usp.br/bjvras/ article/view/26839/28622>. Accessed: Sept. 09, 2016. doi: 10.1590/ S1413-95962010000200007.

CORTIZO, P. et al. Risk factors to incidental leptospirosis and its role on the reproduction of ewes and goats of Espírito Santo state, Brazil. Tropical Animal Health and Production, Edinburgh, v.47, p.231-235, 2015. Available from: < http://link.springer.com/ar ticle/10.1007\%2Fs11250-014-0684-4>. Accessed: Sept. 09, 2016. doi: $10.1007 / \mathrm{s} 11250-014-0684-4$.

COSTA, D.F. et al. Serological study of the Leptospira spp. infection in sheep and goats slaughtered in the State of Paraíba, semiarid of Northeastern Brazil. Semina: Ciências Agrárias, Londrina, v.37, p.819-828, 2016. Available from: < http://www.uel.br/revistas/uel/ index.php/semagrarias/article/viewFile/20974/18600>. Accessed: Sept. 09, 2016. doi: 10.5433/1679-0359.2016v37n2p819.

CUNHA, E.L.P. et al. Research agglutinins anti-Leptospira in goat sera in the state of Pernambuco, Brazil. Revista Brasileira de Medicina Veterinária, Rio de Janeiro, v.21, p.38-40, 1999.

DOS SANTOS, J.P. et al. Seroprevalence and risk factors for Leptospirosis in goats in Uberlândia, Minas Gerais, Brazil. Tropical Animal Health and Production, Edinburgh, v.44, p.101-106, 2012. Available from: $<$ https://link.springer.com/article/10.1007\%2Fs11250-011-9894-1>. Accessed: April. 28, 2017. doi: 10.1007/s11250-011-9894-1.

FAINE, S. et al. Leptospira and leptospirosis. 2.ed. Melbourne: MediSci, 1999. 272p.

FAVERO, A.C.M. et al. Most frequent serovars of leptospires in serological tests of buffaloes, sheeps, goats, horses, swines and dogs from several Brazilian states. Ciência Rural, Londrina, v.32, n.4, p.613-619, 2002. Available from: $<$ http://www.scielo.br/pdf/cr/ v32n4/a11v32n4.pdf>. Accessed: Sept. 09, 2016. doi: 10.1590/S010384782002000400011

GENTILE, R. et al. A review on the role of the water-rat Nectomys squamipes on the transmission dynamics of mansonic schistosomiasis: a long term multidisciplinary study in an endemic area. Oecologia Australis, Rio de Janeiro, v.14, n.3, p.711-725, 2010. Available from: <http://www.oecologiaaustralis.org/ojs/ index.php/oa/article/viewFile/oeco.2010.1403.07/442>. Accessed: Dec. 10, 2016. doi: 10.4257/oeco.2010.1403.07.

GOMES, M.J.P. Genre Leptospira spp. FAVET-UFRGS, 2013. Availablefrom: $<$ http://www.ufrgs.br/labacvet/files/G\%C3\%AAnero $\% 20$ Leptospira\%204-2013-1.pdf>. Accessed: Sept. 09, 2016.

HIGINO, S.S.S. et al. Flock-level risk factors associated with leptospirosis in dairy goats in a semiarid region of Northeastern Brazil. Preventive Veterinary Medicine, Amsterdam, v.109, p.158-161, 2013. Available from: <http://www.sciencedirect.com/science/article/ pii/S0167587712002966>. Accessed: Sept. 09, 2016. doi: 10.1016/j. prevetmed.2012.09.005.

HIGINO, S.S.S.; AZEVEDO, S.S. Leptospirosis in small ruminants: current epidemiological situation in Brazil. Arquivos do Instituto Biológico, São Paulo, v.81, p.86-94, 2014. Available from: <http:// www.scielo.br/pdf/aib/v81n1/1808-1657-aib-81-01-00086.pdf >. Accessed: Sept. 09, 2016. doi: 10.1590/S1808-16572014000100017.

HOSMER, D.; LEMESHOW, S. Applied logistic regression. New York: A Wiley-Interscience Publication, John Wiley \& Sons, 1989. 307p.

IBGE (INSTITUTO BRASILEIRO DE GEOGRAFIA E ESTATÍSTICA). Municipal Liverstock Research. 2014. Available from: <http://www.ibge.gov.br/home/estatistica/economia/ppm/2014/ default_ods.shtm>. Accessed: June 05, 2016.

KEENAN, J. et al. Risk factors for clinical leptospirosis from Western Jamaica. American Journal of Tropical Medicine and Hygiene, Baltimore, v.83, p.633-636, 2010. Available from: $<$ http://www.ajtmh.org/content/83/3/633.long $>$. Accessed: Sept. 09, 2016. doi: 10.4269/ajtmh.2010.09-0609.

LILENBAUM, W. et al. First isolation of leptospires from dairy goats in Brazil. Brazilian Journal of Microbiology, São Paulo, v.38, n.3, p.507-510, 2007a. Available from: <http://www.scielo. br/pdf/bjm/v38n3/v38n3a23.pdf>. Accessed: Dec. 07, 2007. doi: $10.1590 / \mathrm{S} 1517-83822007000300023$.

LILENBAUM, W. et al. A serological study on Brucella abortus, caprine arthritis-encephalitis virus and Leptospira in dairy goats in Rio de Janeiro. The Veterinary Journal, London, v.173, p.408412, 2007b. Available from: <http://www.sciencedirect.com/ science/article/pii/S1090023305003047>. Accessed: Sept. 09, 2016. doi: 10.1016/j.tvj1.2005.12.003. 
LILENBAUM, W. et al. Risk factors associated with leptospirosis in dairy goats under tropical conditions in Brazil. Research in Veterinary Science, London, v.84, p.14-17, 2008. Available from: <http:// www.sciencedirect.com/science/article/pii/S0034528807000872>. Accessed: Sept. 09, 2016. doi: 10.1016/j.rvsc.2007.03.011.

MARTINS, G. et al. Diagnosis and control of an outbreak of leptospirosis in goats with reproductive failure. The Veterinary Journal, London, v.193, p.600-601, 2012. Available from: <http:// www.sciencedirect.com/science/article/pii/S1090023312000342>. Accessed: Sept. 09, 2016. doi: 10.1016/j.tvj1.2012.01.016.

MARTINS, G.; LILENBAUM, W. Leptospirosis in sheep and goats under tropical conditions. Tropical Animal Health and Production, Edinburgh, v.46, p.11-17, 2014 Available from: $<$ http://link.springer.com/article/10.1007\%2 Fs11250-013-0480-6>. Accessed: Sept. 09, 2016. doi: 10.1007/ s11250-013-0480-6.

OLIVEIRA, S.V. et al. Animal reservoirs of leptospirosis: a literature review. Saúde, Santa Maria, v.39, n.1, p.9-20, 2013. Available from: <https://periodicos.ufsm.br/revistasaude/ article/viewFile/5094/pdf_1>. Accessed: Jan. 17, 2017. doi: $10.5902 / 223658345094$

SANTOS, J.P. et al. Seroprevalence and risk factors for Leptospirosis in goats in Uberlândia, Minas Gerais, Brazil. Tropical Animal Health and Production, Edinburgh, v.44, p.101-106, 2012. Available from: <http://link.springer.com/article/10.1007\% 2Fs11250-011-9894-1>. Accessed: Sept. 09, 2016. doi: 10.1007/ s11250-011-9894-1.

SCHMIDT, V. et al. Serological survey of leptospira infection on dairy goats herds on the state of Rio Grande do Sul, Brazil. Ciência Rural, Santa Maria, v.32, p.609-612, 2002. Available from: <http:// www.scielo.br/pdf/cr/v32n4/a10v32n4.pdf>. Accessed: Sept. 09, 2016. doi: 10.1590/S0103-84782002000400010.

SILVA, F.J. et al. The importance of Leptospira interrogans serovars Icterohaemorrhagiae and Canicola in coastal zone and in southern fields of Rio Grande do Sul, Brazil. Pesquisa Veterinária Brasileira, Rio de Janeiro, v.34, n.1, p.34-38, 2014. Available from: <http://www.scielo.br/pdf/pvb/v34n1/06.pdf>. Accessed: Dec. 10, 2016. doi: 10.1590/S0100-736X2014000100006.

SINAN/SVS/MS. Confirmed Cases of Leptospirosis. Brazil, Major Regions and Federated Units from 2000 to 2016. Portal da Saúde SUS, 2017a. Available from: <http://portalsaude.saude.gov.br/ images/pdf/2017/janeiro/11/Casos\%20Leptospirose $\% 202000 \% 20$ a\%202016.pdf>. Accessed: Jan. 17, 2017.

SINAN/SVS/MS. Deaths by Leptospirosis. Brazil, Major Regions and Federated Units from 2000 to 2016. Portal da Saúde SUS, 2017b. Available from: <http://portalsaude.saude.gov.br/images/ pdf/2017/janeiro/11/Obitos \%20Leptospirose $\% 202000 \% 20 \mathrm{a} \% 20$ 2016.pdf>. Accessed: Jan. 17, 2017.

THRUSFIELD, M. Veterinary Epidemiology. 3.ed. Oxford: Blackwell Scientific Publication, 2007. 624p.

TOPAZIO, J. et al. Antibodies to Leptospira interrogans in goats and risk factors of the disease in Santa Catarina (West side), Brazil. Research in Veterinary Science, London, v.99, p.53-57, 2015. Available from: $<$ http:// www.sciencedirect.com/science/article/pii/S0034528815000399>. Accessed: Sept. 09, 2016. doi: 10.1016/j.rvsc.2015.01.014.

VIRGINIE, M. et al. Epidemiology of Leptospirosis. Revista Cubana Medicina Tropical, Habana, v.54, n.1, p.7-10, 2002. Available from: $<\mathrm{http} / /$ scielo.sld.cu/scielo.php?script=sci_arttext\&pid=S0375076020 02000100002\&lng=es\&tlng=es>. Accessed: Dec. 10, 2016. 